\title{
Aplikasi Pakan Konsentrat Berbasis Bahan Lokal Untuk Meningkatkan Kualitas Karkas Sapi (Sapi Pesisir)
}

\author{
Khasrad \\ Jurusan Produksi Ternak Fakultas Peternakan Universitas Andalas, Padang
}

\begin{abstract}
The present research was studied the effect of feeding level and fattening period on the carcass characteristics (pencentage of carcass, back fat thicksess and loin eye area) of Pesisir cattle. Treatments of feeding included: $A I=50 \%$ concentrate $+50 \%$ ammoniated rice straw, $A 2=75 \%$ concentrate $+25 \%$ ammoniated rice straw. The feed were offered in two fattening periods of $B 1=3$ months and $B 2=4$ months. Data were statistically analyzed in randomized block design with three blocks. Results showed that there was no interaction effect between the levels of feeding and fattening periods to the percentage of carcass, the back fat thickness and the loin eye area of the Pesisir cattle ( $P$ $>0,05$ ). The higher of concentrate percentage used in the feed and the longer the fattening periad were followed by the thicker the back fat and the wider the loin eye area $(P<0.05)$.
\end{abstract}

Key words: Pesisir cattle, carcass characteristic, feedlot fattening.

\section{Pendahuluan}

Dalam penjualan karkas/ daging diperlukan suatu acuan peringkat komersil karkas/daging. Peringkat karkas, baik kuantitas maupun kualitas bisa sebagai standar dan membantu konsumen, sehingga konsumen mendapatkan daging sesuai dengan yang diinginkannya. Apalagi untuk sapi Pesisir sampai saat ini karakteristik karkasnya belum begitu diungkapkan, baik melalui penelitian lapangan maupun laboratorium. Padahal sapi Pesisir ini merupakan plasma nutfah Sumatera Barat yang perlu dipikirkan usaha pengembangannya.

Sapi Pesisir atau biasa disebut masyarakat sebagai bantiang ratuih atau jawi ratuih ditemukan di Kabupaten Pesisir Selatan (Saladin, 1983). Populasi sapi di Kabupaten Pesisir Selatan pada tahun 2001 tercatat sejumlah 96.443 ekor (BPS Sumbar, 2001). Hampir semua dari populasi ini adalah sapi lokal (sapi Pesisir), sebagian kecil lainnya terdiri dari sapi Bali, hasil IB Bali dan hasil IB Simmental. Sebagian besar sapi Pesisir ini dipelihara masyarakat secara tradisional dan menyebar secara merata di Kabupaten Pesisir Selatan.

Selama ini pendugaan kuantitas produksi dan penilaian terhadap karkas sapi Pesisir dilakukan dengan cara tradisional, yaitu secara observasi dan palpasi pada bagian - bagian tertentu tubuh ternak antara lain pada pinggang dan paha. Karkas sapi adalah bagian tubuh hasil pemotongan setelah dikurangi darah, kepala, keempat kaki pada bagian bawah (mulai dari carpus dan tarsus), kulit, saluran pencernaan, usus, urine, jantung. tenggorokan, paru - paru, limpa, hati 
dan jaringan - jaringan lemak yang melekat pada bagian tubuh, sedangkan ginjal sering dimasukkan sebagai karkas (Lawrie, 1985). Faktor utama yang diperhatikan untuk menilai karkas yang dipasarkan adalah; bobot karkas, persentase karkas, tebal lcmak punggung dan potongan karkas yang dapat dijual (Swatland, 1984).

Penggemukan merupakan usaha terbaik dalam meningkatkan produktivitas dan kualitas karkas sapi Pesisir, karena pada usaha penggemukan dapat diberikan pakan yang sesuai dengan kebutuhan, berenergi tinggi dan bermutu baik. Sumatera Barat mempunyai potensi yang besar dalam pengembangan sapi lokal, karena banyak terdapat hasil limbah pertanian dan industri sebagai bahan pakan, namun saat ini potensi tersebut belum termanfaatkan secara optimal.

Diantara sumber bahan pakan yang banyak dijumpai di Sumatera Barat adalah dedak padi, bungkil kelapa, jagung, sagu, jerami padi dan lain-lain. Jerami padi merupakan hasil ikutan pertanian yang produksinya cukup tinggi dan hampir tersedia sepanjang tahun. Menurut Laporan Dinas Pertanian Tanaman Pangan dan Perkebuman Sumatera Barat (2002) luas panen tanaman padi mencapai $426,325 \mathrm{Ha}$, dengan prediksi produksi jerami per hektar sekitar 7 ton maka jumlah jerami yang dihasilkan mencapai 2.984 .275 ton. Menurut Garret et al. (1974) perlakuan amoniasi pada jerami padi dapat meningkatkan kadar nitrogen bahan $5-6 \%$, sekaligus meningkatkan degradasi nitrogen.

Respon produktivitas ternak dan kualitas karkas serta daging dapat berbeda dalam bangsa yang sama. Perbedaan respon produk- tivitas juga dapat terjadi diantara bangsa, jenis kelamin yang berbeda dan diantara faktor lingkungan termasuk nutrisi (pakan) serta periode waktu penggemukan. Pakan dengan kualitas yang baik, umumnya dapat meningkatkan efisiensi produksi, namun demikian biaya pakan harus diperhitungkan dengan nilai produk yang dihasilkan (Bowker et al., 1978).

Berdasarkan permasalahan di atas maka perlu dilakukan suatu upaya peningkatan produktivitas dan kualitas karkas atau daging sapi Pesisir dengan melakukan pemeliharaan secara intensif dengan periode waktu penggemukan yang berbeda. Seluma pemeliharaan diberikan ransum konsentrat yang mengandung protein dan energi yang tinggi serta jerami padi amoniasi yang berkualitas baik.

Tujuan penelitian adalah untuk mengetahui pengaruh level pemberian makanan dan lama penggemukan terhadap karakteristik karkas (persentase karkas, tebal lemak punggung dan luas urat daging mata rusuk) sapi Pesisir.

Hipotesis yang dapat dikemukakan dalam penelitian ini adalah tingkat pemberian ransum yang berbeda dan lama periode penggemukan mempengaruhi karakteristik karkas (persentase karkas, tebal lemak punggung dan luas urat daging mata rusuk) sapi Pesisir.

\section{Materi dan Metode Penelitian}

\section{Bahan dan Peralatan Peaelitian}

Teraak. Sapi yang digunakan dalam penelitian ini adalah sapi Pesisir jantan umur $2-2,5$ tahun sebanyak 12 ckor, yang berasal dari Kecamatan Ranah Pesisir Kabupaten Pesisir Selatan. Berat awal sapi yang 
digunakan dalam penelitian ini berkisar antara 126 - $170 \mathrm{~kg}$. Setiap sapi ditempatkan di dalam kandang individu dan mengalami masa adaptasi selama 30 hari.

Ransum. Ransum disusun berdasarkan bahan yang tersedia yaitu dengan perbandingan bahan kering konsentrat $(K)$ dan jerami amoniasi (JA) $50 \%$ : $50 \%$ untuk perlakuan Al dan $75 \%$ dan $25 \%$ untuk perlakuan A2. Konsentrat tersusun dari kombinasi dedak, jagung, bungkil kelapa, sagu, mineral dan garam. Susunan ransum perlakuan dan komposisinya dapat dilihat pada Tabel - tabel berikut.

Peralatan. Alat yang digunakan dalam penelitian, antara lain: timbangan sapi, timbangan pakan, seperangkat peralatan abatoir, timbangan karkas, pengukur tebal lemak punggung dan lembar plastik grid untuk pengukur luas urat daging mata rusuk.

Tabel 1. Susunan Ransum Konsentrat ( $\%$ BK)

\begin{tabular}{lc}
\hline \multicolumn{1}{c}{ Bahan Makanan } & Persentase (\%) \\
\hline Dedak padi & 40 \\
Jagung & 18 \\
Bungkil kelapa & 30 \\
Sagu & 10 \\
Mineral & 1 \\
Garam & 1 \\
\hline Total & 100 \\
\hline
\end{tabular}

Tabel 2. Komposisi Kimia Bahan Penyusun Ransum Percobaan (\% BK)

\begin{tabular}{lccrcccc}
\hline \multicolumn{1}{c}{ Bahan } & BK & PK & \multicolumn{1}{c}{ SK } & LK & Abu & BETN & TDN \\
\hline 1. Dedak Padi & 85,89 & 12,58 & 14,18 & 5,69 & 6,92 & 60,63 & 62,90 \\
2. Jagung & 89,33 & 10,23 & 3,98 & 3,94 & 3,04 & 78,81 & 80,80 \\
3. Bungkil Kelapa & 84,09 & 18,09 & 14,99 & 9,78 & 8,19 & 48,95 & 91,35 \\
4. Sagu & 25,12 & 2,53 & 4,46 & 0,17 & 2,99 & 89,85 & 83,84 \\
5. Mineral & 96 & & & & & & \\
6. Garam & 100 & & & & & & \\
7. Jerami Amoniasi & 46,60 & 7,81 & 39,92 & 1,79 & 20,80 & 29,68 & 46,00 \\
\hline Sumber : Analisa Labor Nutrisi Ruminan & & & & &
\end{tabular}

Tabel 3. Komposisi Kimia Ransum Perlakuan (\%)

\begin{tabular}{lcc}
\hline \multirow{2}{*}{ Zat Makanan } & \multicolumn{2}{c}{ Ransum Perlakuan (Faktor A) } \\
\cline { 2 - 3 } & $\mathrm{A} 1(50 \% \mathrm{~K}+50 \% \mathrm{JA})$ & $\mathrm{A} 2(75 \% \mathrm{~K}+25 \% \mathrm{JA})$ \\
\hline Bahan Kering & 63,37 & 71,75 \\
Protein Kasar & 10,06 & 11,36 \\
Serat Kasar & 25,63 & 18,47 \\
Lemak Kasar & 3,86 & 4,90 \\
Abu & 13,43 & 9,75 \\
BETN & 45,89 & 54,00 \\
TDN & 60,74 & 68,12 \\
\hline Sumber : Analisa Labor Nutrisi Ruminan &
\end{tabular}




\section{Metode Penelitian}

Data yang diperoleh diolah secara statistik dengan analisis ragam dengan menggunakan rancangan acak kelompok. Penelitian ini merupakan percobaan berfaktor dalam RAK 2 x 2 dengan 3 kelompok. Faktor pertama (faktor A) adalah 2 tingkat pemberian ransum yaitu: $\mathrm{Al}=50 \%$ konsentrat $+50 \%$ jerami amoniasi dan $\mathrm{A} 2=75$ $\%$ konsentrat $+25 \%$ jerami amoniasi, Faktor kedua (faktor B) adalah lama penggemukan yaitu $\mathrm{B} 1=3$ bulan dan B2 $=4$ bulan. Sedangkan sebagai kelompok adalah berat awal sapi yaitu; I $=126-140 \mathrm{~kg}, \mathrm{II}=141$ $155 \mathrm{~kg}$ dan III $=156-170 \mathrm{~kg}$

Model statistik yang digunakan dalam penelitian ini sesuai dengan pendapat Steel dan Torrie (1993) yaitu:

$Y(i j k)=\mu+\alpha i+\beta j+\alpha \beta(i j)+r k+$ dimana:

$$
\text { sijk, }
$$

$\mathrm{Y}(\mathrm{ijk})=$ nilai pengamatan pada perlakuan i dan j, ulangan ke $\mathrm{k}$

$\mu \quad=$ nilai tengah umum

$\alpha \mathrm{i}=$ pengaruh periakuan ke $\mathrm{i}$ dari bangsa sapi

Bj = pengaruh perlakuan ke $\mathrm{j}$ lams penggemukan

$\alpha \beta(i j)=$ pengaruh interaksi perlakuan ke idan $j$

$\mathrm{nk} \quad=$ pengaruh kelompok ke $\mathrm{k}$

eijk = kesalahan percobaan

Peubah yang diamati dalam penelitian ini adalah : karakteristik karkas sapi Pesisir yaitu : persentase karkas, tebal lemak punggung dan luas urat daging mata rusuk.

Persentase Bobot Karkas. Dihitung berdasarkan perbandingan antara bobot karkas panas (segar) dengan bobot potong dikalikan 100 persen (Tulloh, 1978).

Tebal Lemak Punggung. Ditentukan dengan cara mengukur tebal lemak pada kurang lebih tigaperempat panjang irisan penampang melintang urat daging mata rusuk antara rusuk ke 12 dan 13, dengan menggunakan USDA Preliminary Cutability Grade (Soeparno, 1992).

Luas Urat Daging Mata
Rusuk. Dihitung dengan cara mengukur luas penampang urat daging mata rusuk (Longissimus dorsi) pada irisan antara rusuk 12 dan 13 (Soepamo, 1992). Permukaan irisan urat daging mata rusuk ditempel dengan plastik transparan, kemudian digambar dengan spidol. Gambar bidang permukaan penampang melintang urat daging mata rusuk ditera dengan plastik grid.

\section{Hasil Dan Pembahasan}

\section{Perseutase Karkas}

Rataan persentase karkas sapi Pesisir yang dipelihara secara intensif dengan lama penggemukan yang berbeda dapat dilihat pada Tabel 4 berikut.

Tabel 4. Rataan Persentase Karkas Sapi Pesisir Setelah Dipotong (\%)

\begin{tabular}{cccc}
\hline Faktor A & \multicolumn{2}{c}{ Faktor B (Lama Penggemukan) } & \multirow{2}{*}{ Rataan } \\
\cline { 2 - 3 } (Level Ransum) & B1 (3 Bln) & B2 (4 Bin) & \\
\hline A1 $(50 \% \mathrm{~K}+50 \%$ JA) & 51,92 & 52,77 & 52,34 \\
A2 $(75 \% \mathrm{~K}+25 \%$ JA) & 52,37 & 53,66 & 53,00 \\
\hline Rataan & $52,13^{\mathrm{a}}$ & $53,21^{\mathrm{b}}$ & 52,67 \\
\hline
\end{tabular}

Keterangan : Supersikrip yang berbeda menurut baris yang sama menunjukan pengaruh berbeda nyata $(\mathrm{P}<0,05)$ 
Dari hasil analisis ragam diketahui bahwa tidak terdapat interaksi antara tingkat pemberian ransum dengan lama penggemukan terhadap persentase karkas $(P>0,05)$. Sedangkan faktor lama penggemukan memberikan pengaruh yang berbeda nyata terhadap persentase karkas $(\mathrm{P}<$ 0,05 ) dan faktor tingkat pemberian ransum tidak berpengaruh nyata terhadap persentase karkas.

Rataan persentase karkas sapi Pesisir yang didapatkan selama penelitian berkisar antara 51,92 $53,66 \%$. Lama penggemukan berpengaruh nyata terhadap persentase karkas, dimana persentase karkas sapi yang digemukkan selama 4 bulan $(53,21 \%)$ lebih tinggi dari persentase karkas yang digemukkan selama 3 bulan $(52,13 \%)$ (Gambar 1), Adanya perbedaan ini menunjukkan bahwa sapi tersebut masih dalam usia produktif, sehingga semakin lama digemukkan bobot badan semakin bertambah sebagai akibat bertambahnya deposisi lemak dan perluasan serat otot. Dari data yang diperoleh dalam penelitian ini menegaskan kembali teori pertumbuhan bahwa bobot karkas meningkat dengan meningkatnya umur ternak karena pertumbuhan atau per- tambahan bobot jaringan - jaringan yang menyusun karkas (daging. tulang dan lemak). Setelah hewan mencapai dewasa tubuh maka pertambahan bobot badannya adalah menurun (Berg dan Butterfield, 1976). Dewasa tubuh pada sapi Pesisir dicapai pada umur 4 tahun keatas (Saladin, 1984). Swatland (1984) menyatakan bahwa sesudah usia pubertas (pada sapi umur sekitar 2 - 3 tahun) perkembangan komponen jaringan karkas lebih didominasi oleh perkembangan lemak, sementara muskulus (otot) berkembang secara lambat, sedangkan tulang relatif berhenti.

\section{Tebal Lemak Punggung}

Rataan tebal lemak punggung Sapi Pesisir yang dipelihara secara intensif dengan periode penggemukan yang berbeda, dapat dilihat pada Tabel 5.

Hasil analisis ragam menunjukan bahwa tidak ada pengaruh interaksi antara level pemberian ransum dengan lama penggemukan terhadap tebal lemak punggung sapi Pesisir, sedangkan pengaruh masing masing faktor memperlihatkan pengaruh yang nyata terhadap tebal lemak punggung $(\mathrm{P}<0,05)$.

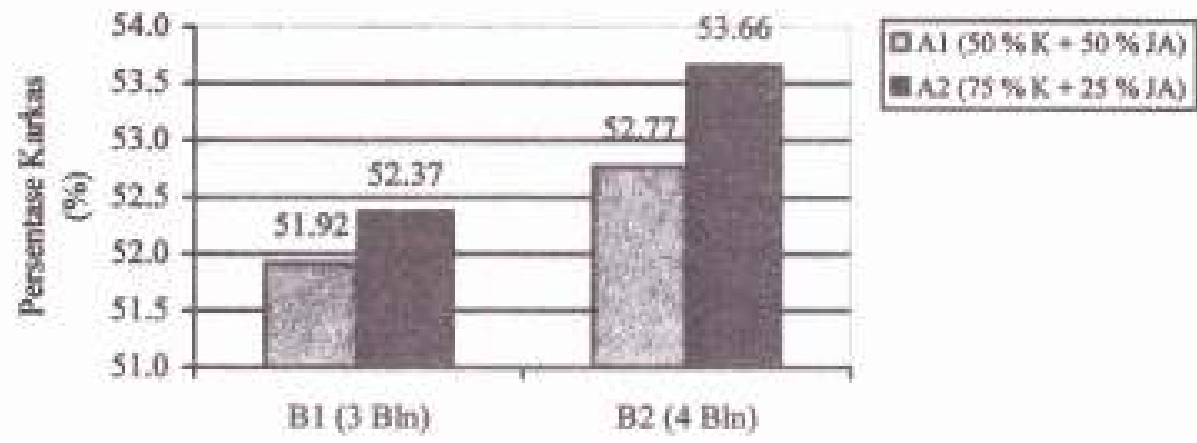

Lama Penggemukan

Gambar 1. Histogram Persentase Karkas Sapi Pesisir 
Tabel. 5. Rataan Tebal Lemak Punggung Sapi Pesisir Setelah Dipotong (mm)

\begin{tabular}{cccc}
\hline Falktor A & \multicolumn{2}{c}{ Faktor B (Lama Penggemukan) } & \\
\cline { 2 - 3 }$($ Level Ransum) & B1 $(3 \mathrm{Bln})$ & B2 $(4 \mathrm{Bln})$ & Rataan \\
\hline A1 $(50 \% \mathrm{~K}+50 \% \mathrm{JA})$ & 2,167 & 2,500 & $2,334^{\mathrm{A}}$ \\
$\mathrm{A} 2(75 \% \mathrm{~K}+25 \% \mathrm{JA})$ & 2,500 & 3,333 & $2,916^{\mathrm{b}}$ \\
\hline Rataan & $2,334^{\mathrm{A}}$ & $2,916^{\mathrm{B}}$ & 2,625 \\
\hline
\end{tabular}

Keterangan : Superakrip yang berboda menurut baris dan koiom yang sama menumjukan pengaruh berteda nyata $(\mathrm{P}<0,05)$

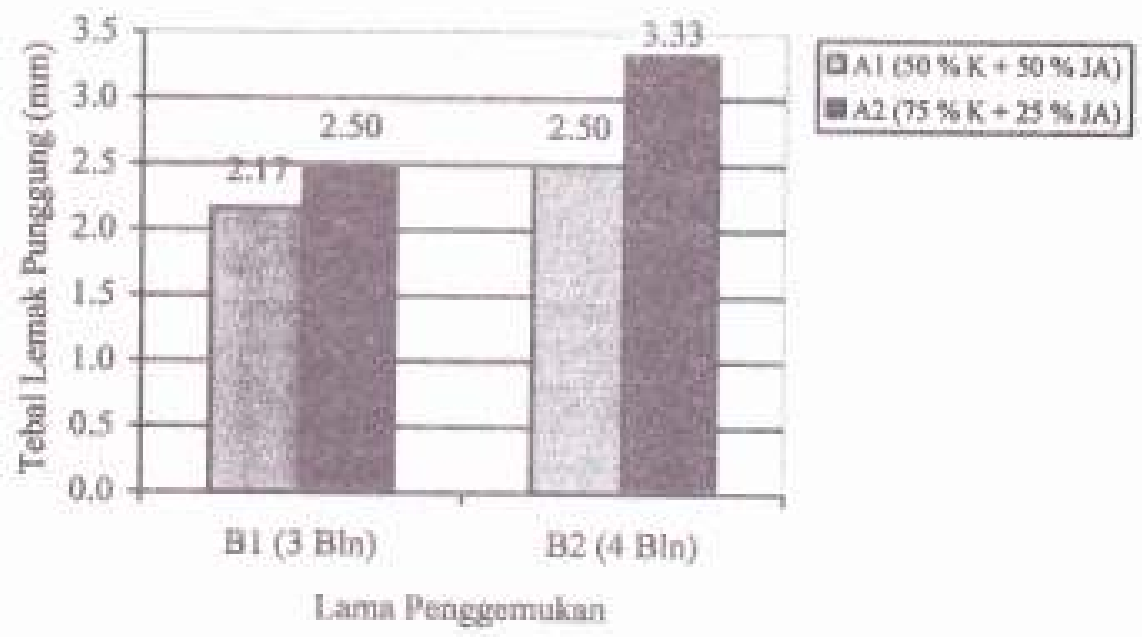

Gambar 2. Histogram Tebal Lemak Punggung Sapi Pesisir

Tingkat pemberian ransum pada perlakuan Al ( $50 \%$ konsentrat $+50 \%$ jerami amoniasi) dengan nilai rataan 2,334 mm berbeda sangat nyata $(\mathrm{P}<0,05)$ terhadap A2 $(75 \%$ konsentrat $+25 \%$ jerami amoniasi) dengan nilai rataan $2,916 \mathrm{~mm}$ (Gambar 2). Tingginya rataan tebal lemak punggung pada $\mathrm{A} 2$ disebabkan karena pemberian konsentrat lebih tinggi dibandingkan dengan Al. Sapi dalam pertumbuhan yang diberi konsentrat tinggi akan terjadj penimbunan lemak tubuh terutama lemak punggung atau subcutan. Ketebalan lemak punggung ini merupakan indikator untuk menentukan perlemakan tubuh atau karkas. Tebal lemak punggung sapi Pesisir ini lebih rendah dibandingkan sapi Sumba Onggole (SO). Hasil penelitian Ngadiono (1995) terhadap sapi SO yang diberikan pakan konsentrat $85 \%$ selama penggemukan 4 bulan tebal lemak pungrungnya mencapai 0,09 inci. Magdalena (1991) menyatakan bahwa umur temak dan makanan yang dimakan oleh ternak mempengaruhi perlemakan dalam tubuh ternak.

Nutrisi kemungkinan besar merupakan faktor lingkungan terpenting yang mempengaruhi komposisi karkas, terutama terhadap proposi kadar lemak (Soeparno 1992). Juga ditambahkan bahwa nutrisi mempengaruhi perlemakan karkas pada berat tubuh tertentu. Peningkatan energi pakan dan konsumsi energi akan meningkatkan kadar lemak karkas, asalkan protein tidak merupakan pembatas. Pening- 
katan energi ransum akan meningkatkan lemak subkutan, proporsi lemak karkas dan menurunkan proporsi daging.(Arthod et al, 1977).

Lama pengemukan juga memberikan pengaruh nyata $(\mathrm{P}<0,05)$, dimana lama penggemukan 4 bulan dengan nilai rataan $2,916 \mathrm{~mm}$ lebih tinggi dari pada 3 bulan dengan nilai rataan $2,334 \mathrm{~mm}$. Semakin tebalnya lemak punggung pada penggemukan selama 4 bulan dibandingkan dengan 3 bulan, karena akumulasi penimbunan lemak pada penggemukan yang lebih lama semakin meningkat. Menurut Soeparno (1992) kecepatan pertumbuhan yang terjadi sesudah umur pubertas berturut - turut dari yang paling cepat adalah lemak, kemudian muskulus dan tulang yang relatif sudah berhenti. Swatland, (1984) menyatakan bahwa deposisi lemak pada saat penggemukan mengikuti 3 phase yaitu perlemakan di organ dalam, ginjal dan mesenterium, kemudian jaringan subcutan dan intermuskaler, dan yang terakhir adalah lemak intramuskuler (marbling).

\section{Luas Urat Daging Mata Rusuk}

Rataan luas urat daging mata rusuk sapi Pesisir yang dipelihara secara intensif dengan periode penggemukan yang berbeda, dapat di lihat pada Tabel 6 .

Hasil analisis ragam menunjukan bahwa tidak terdapatnya interaksi antara faktor A (tingkat pemberian ransum) dan faktor B (lama penggemukan) terhadap luas urat daging mata rusuk. Sedangkan masing - masing faktor tingkat pemberian ransum dan lama penggemukan memperlihatkan pengaruh nyata $(P<0,05)$ terhadap luas urat daging mata rusuk sapi Pesisir.
Luas urat daging mata rusuk daging sapi dengan tingkat pemberian ransum Al ( $50 \%$ konsentrat $+50 \%$ jerami amoniasi) dengan nilai rataan $67,42 \mathrm{~cm}^{2}$ berbeda nyata $(\mathrm{P}<0,05)$ dengan A2 (75\% konsentrat $+25 \%$ jerami Amoniasi) dengan nilai rataan $69,50 \mathrm{~cm}^{2}$ (Gambar 3). Semakin tinggi tingkat konsentrat pada ransum, maka luas urat daging mata rusuk semakin meningkat juga. Tingginya rataan luas urat daging mata rusuk pada sapi yang diberi konsentrat tinggi $(75 \%)$ menyebabkan peningkatan penimbunan lemak dan protein pada otot daging. Peningkatan luas urat daging mata rusuk ini juga erat hubungannya dengan peningkatan berat karkas. Dengan meningkatnya berat karkas berarti semakin bertambah luas urat daging mata rusuk. Sesuai dengan pendapat Yusnaweti (1986) bahwa adanya hubungan yang positif antara luas urat daging mata rusuk dengan bobot karkas pada sapi PO jantan. Setiap pertambahan $1 \mathrm{~cm}^{2}$ luas urat daging mata rusuk menyebabkan pertambahan bobot karkas sebesar $2,90 \mathrm{~kg}$.

Lama penggemukan juga memberikan pengaruh yang nyata $(\mathrm{P}$ $<0,05$ ) terhadap luas urat daging mata rusuk sapi Pesisir, yaitu penggemukan selama 4 bulan dengan rataan $69,75 \mathrm{~cm}^{2}$ lebih luas urat daging mata rusuknya dibandingkan dengan sapi yang digemukkan selama 3 bulan yaitu dengan rataan $67,167 \mathrm{~cm}^{2}$.

Tingginya rataan luas urat daging mata rusuk dengan lama penggemukan 4 bulan disebabkan karena dengan semakin lamanya penggemukan maka akan terjadi peningkatkan ukuran serabut otot. 
Tabel. 6. Rataan Luas Urat Daging Mata Rusuk Sapi Pesisir $\left(\mathrm{cm}^{2}\right)$

\begin{tabular}{cccc}
\hline Faktor A & \multicolumn{2}{c}{ Faktor B (Lama Penggemukan) } & \\
\cline { 2 - 3 } (Level Ransum) & B1 (3 Bln) & B2 (4 Bln) & Rataan \\
\hline A1 (50\% K+50\% JA) & 66,33 & 68,50 & $67,42^{\mathrm{A}}$ \\
A2 (75\% K+25\% JA) & 67,00 & 71,00 & $69,50^{\mathrm{b}}$ \\
\hline Rataan & $67,17^{\mathrm{A}}$ & $69,75^{\mathrm{B}}$ & 68,46
\end{tabular}

Keterangan : Superskrip yang berbeda menurut baris dan kolom yang sama menunjukan pengaruh berbeda nyata $(P<0,05)$

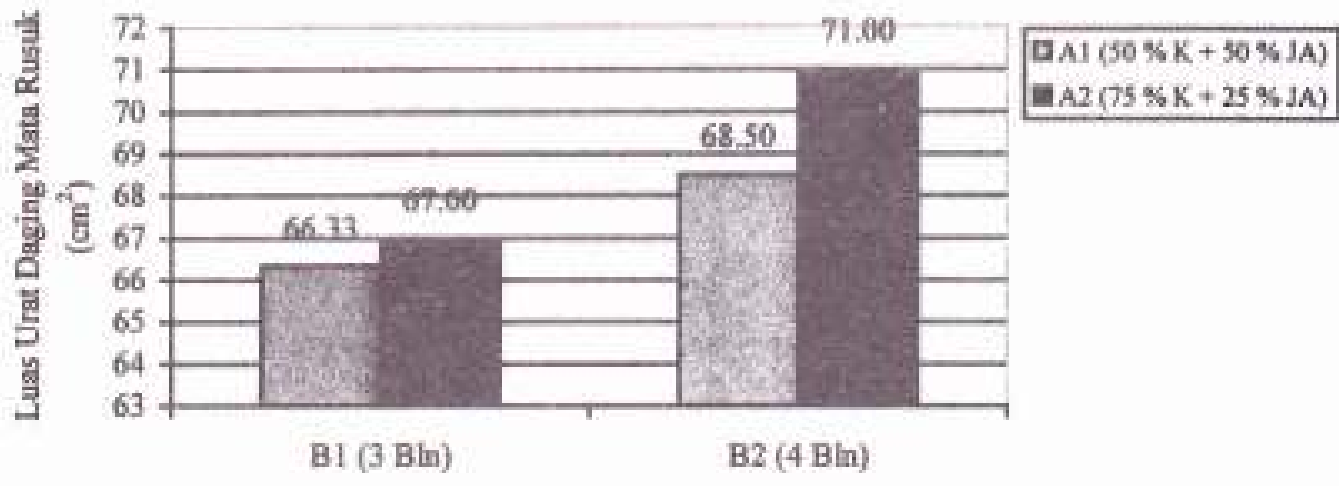

Lama Panggemukan

Gambar 3. Histogram Luas Urat Daging Sapi Pesisir

Selain juga menunjukkan kecenderungan adanya peningkatan lemak pada otot mengikuti lamanya waktu penggemukan. Sesuai dengan pen-dapat Romans dan Ziegler (1974) bahwa besarnya proporsi urat daging karkas dapat ditentukan dari luas urat daging mata rusuk. Arka (1984) melaporkan umur sapi memberikan pengaruh yang sangat nyata terhadap luas urat daging mata rusuk. Dengan bertambahnya umur maka luas urat daging mata rusuk juga bertambah.

\section{Kesimpulan}

1. Tidak adanya interaksi antara level pemberian ransum dengan lama penggemukan terhadap persentase karkas, tebal lemak punggung dan luas urat daging mata rusuk sapi Pesisir ( $\mathrm{P}$ > $0,05)$.
2. Faktor level pemberian ransum berpengaruh nyata $(\mathrm{P}<0,05)$ terhadap tebal lemak punggung dan luas urat daging mata rusuk. Semakin tinggi persentase konsentrat dalam ransum pertumbuhan semakin cepat, lemak punggung semakin tebal dan urat daging mata nusuk semakin luas.

3. Karakteristik karkas sapi Pesisir yang digemukkan selama 4 bulan lebih baik dari yang digemukkan selama 3 bulan, dimana persentase karkas semakin tinggi, lemak punggung makin tebal dan luas urat daging mata rusuk juga semakin meningkat $(\mathrm{P}<0,05)$.

4. Sapi Pesisir sangat prospektif untuk dikembangkan karena mempunyai persentase karkas yang tinggi $51,92-53,66 \%$ dan lemak punggung yang tipis $(2,167$ 
$-3,333 \mathrm{~mm}$ ). Apalagi saat ini konsumen lebih menyukai daging yang mengandung lemak yang sedikit.

\section{Saran}

Hasil penelitian ini dapat sebagai bahan masukan bagi pemerintah dalam penyusunan standar kualitas karkas sapi lokal.

\section{Daftar Pustaka}

Arka, L.B. 1984. Pengaruh Penggemukan Terhadap Kualitas Daging dan Karkas pada Sapi Bali. Disertasi Doktor. Universitas Padjadjaran, Bandung.

Arthoud, V.H., R.W. Mandigo, R.M. Koch and A.W. Kotula. 1977. Carcas composition, quality and palatability attribute of bull and steers. Fed different energy levels and killed at four ages. J. Anim. Sci. 44 (I) : 53-64.

Berg, R.T. dan R.M. Butterfield. 1976. New Concepts of Cattle Growth. Sydney University Press.

Bowker, W.A.T., R.G. Dumday, J.E. Frisch, R.A. Swan dan N.M. Tulloh. 1978. A Course Manual and Beef Cattle Management and Economic. A.A.U.C.S, Canbera. Australia.

BPS Tingkat I Sumatera Barat. 2001. Sumatera Barat Dalam Angka.

Dinas Pertanian Tanaman Pangan dan Perkebunan. 2002. Laporan Tahunan, Dinas Pertanian Tanaman Pangan dan Perkebunan. Propinsi Sumatera Barat.
Garret, W.N., H.G. Walkel, G.O. Kohler, A.C. Waiss, R.P. Graham, N.E. Eas dan M.R. Hart. 1974. Nutritive Value of $\mathrm{NaOH}$ and $\mathrm{NH}_{3}$ Treated Straws. Prod. West. Sect. Amer. Soc. Anim. Sci. 25: 317-320.

Lawrie, R.A. 1985. Meat Science. $4^{\text {th }}$. Ed. Pergamon Press, Oxford-New York.

Magdalena. 1991. Hubungan Antara Luas Udamaru dan Tebal Lemak Punggung Terhadap Persentase Karkas Kerbau Jantan. Fakultas Peternakan, Universitas Andalas. Tidak Dipublikasikan.

Ngadiono, N. 1995. Pertumbuhan Serta Sifat-Sifat Karkas dan Daging Sapi Sumba Ongole, Brahman Cross dan Australian Commercial Cross yang Dipelihara Secara Intensif Pada Berbagai Bobot Potong. Disertasi Doktor. Program Pascasarjana Institut Pertanian Bogor, Bogor.

Romans, J. R. dan P.T. Ziegler. 1974. The Meat We Eat. $10^{\text {th }}$ ed. The Interstate Printers \& Publisher, Inc., Danville, Illinois.

Saladin, R. 1983. Penampilan Sifatsifat Produksi dan Reproduksi Sapi Lokal Pesisir Selatan di Propinsi Sumatera Barat. Disertasi, Program Pascasarjana Institut Pertanian Bogor, Bogor.

1984. Pedoman Beternak Sapi Potong. Fakultas Peternakan Universitas Andalas, Padang. Tidak Dipublikasikan.

Soeparno. 1992. Ilmu dan Teknologi Daging. Gajah Mada University Press. Yogyakarta. 
Steel, R.D.G. dan J.T. Torrie. 1993. Principles and Procedure of Statistics. McGraw Hill Book Co. L.C. New York.

Swatland, H.J. 1984. Strukture and Development of Meat Animals. Prentice-Hall, Inc., Englewood Cliffs, New Jersey.

Tulloh, N.M. 1978. Growth, development, body composition, breeding and management. A Course Manual in Beef Cattle Management and Economics. W.A.T. Bowker, R.G. Dumsday, J.E. Frisch, R.A. Swan and N.M. Tulloh (Eds), Australian Vice Chancellors Committee. Academity Press. Pty. Ltd, Brishbane. 59-91.

Alamat korespondensi: Dr. Ir. Khasrad, MS.

Jurusan Produksi Ternak, Fakultas Peternakan

Universitas Andalas, Kampus Limau Manis, Padang

Telp. 0751-74208 Fax: 0751-71464, HP: 08126799567

Diterima: 15 Agustus 2007, Disetujui: 24 September 2007 